\title{
In vitro Conversion of Alginate-encapsulated Nodal Segments of Rosa hybrida L. 'Kardinal' Into Complete Plantlets
}

\author{
"Abdel-Rahman, S.S.A. ${ }^{1}$ and Ina Pinker ${ }^{2}$
}

${ }^{1}$ Floriculture Department, Faculty of Agriculture, Assiut University, Assiut, Egypt

${ }^{2}$ Humboldt University of Berlin, Horticultural Plant Systems, D-14195 Berlin, Germany

*Corresponding author: Shehatasayed54@yahoo.com

Received on: 14/3/2019

Accepted for publication on: $7 / 4 / 2019$

\section{Abstract}

The present experiments were conducted at Humboldt University of Berlin, Horticultural Plant Systems, Germany during 2012 and 2013 seasons, to clarify the nutrient requirements for regeneration of encapsulated nodal segments of Rosa hybrida 'Kardinal', as well as define the nutrient losses from the beads during incubation on nutrient-free media. Shoot cultures were cultivated on modified MS medium. For encapsulation, 4 to $5 \mathrm{~mm}$ nodal segments were isolated 3 weeks after subculturing. The nodal segments were put in 3\% Na-alginate diluted in the modified MS medium with various sucrose concentrations (30 to $90 \mathrm{~g}^{-1}$ ) and 0.5 to $2 \mathrm{mg} \mathrm{l}^{-1}$ indole-3-butyric acid (IBA). To improve the nutrient supply, $85 \mu 1,95$ $\mu 1$ or $105 \mu \mathrm{l}$ of Na-alginate with one nodal segment was dropped in to $75 \mathrm{mM}$ $\mathrm{CaCl}_{2}$ dissolved in the same media contains Na-alginate for $30 \mathrm{~min}$ hardening. The results showed that already after $24 \mathrm{~h}$ incubation on the water-agar-medium more than $90 \%$ of nitrate was diffused out of the beads. The reduction of wateragar-medium volume from $25 \mathrm{ml}$ to $7 \mathrm{ml}$ reduced the nutrient leakage and improved the shoot formation from 40 to $90 \%$. The root regeneration of the encapsulated nodal segments also increased from $40 \%$ to $80 \%$ either by increasing the bead volume from 85 to $105 \mu$ or the sucrose concentration from 30 to $50 \mathrm{~g} \mathrm{l}^{-1}$ in the propagation medium. The highest conversion (approximately 50\%) was found after supplying $1 \mathrm{mg} \mathrm{l}^{-1}$ IBA and $90 \mathrm{~g} \mathrm{l}^{-1}$ sucrose to the bead gel matrix.

Keywords: Rosa hybrida, artificial seeds, gel matrix compounds, bead volume, nutrient leakage

\section{Introduction}

Creation of 'artificial seeds' by encapsulation of somatic embryos, shoot tips and buds has been under discussion since the first publication of this idea by Murashige (1977). Using nodal segments or shoot tips for encapsulation has some advantages in comparison with somatic embryos. First, a higher genetic stability of plant material of the nodal segments or shoot tips can be expected (Lata et al., 2011, Standardi and Micheli, 2012, Sharma et al., 2013 and
Gholami and Kaviani, 2018). This seems to be very important for plants with a high mutability like Chrysanthemum (Teixeira da Silva, 2004) and also Rosa spp. in which somaclonal variation was found after callus culture (Rout et al., 1999). Second, the non-embryogenic vegetative propagules can be used for mass clonal propagation of high value crops at a reasonable cost especially when somatic embryos are not available for encapsulation (Maruyama et al., 1997, Chand and Singh, 2004, 
Rai et al., 2008 and Elangomathavan et al., 2017). In the unipolar nodal segments not only growing processes like those in the bipolar somatic embryos have to be started, but also the energy consuming and oxygen required regeneration process of adventitious roots has to be initiated and completed (Standardi and Piccioni, 1997 and Calamar and De Klerk, 2002). Up to now, encapsulation of shoot segments with $\mathrm{Ca}$-alginate has been published for various species (Singh et al., 2010, Carlson and West, 2016, Gantait et al., 2017 and Sharma and Sharma, 2018).

Most protocols used a modified medium after Murashige and Skoog (1962) as growing medium guarantee the nutrient supply for the encapsulated plant material over a long period of time. If growing media was used without nutrient supply, the growing response of the encapsulated plant material became low or sometimes no conversion could be occurred (Pattniak and Chand, 2000, Pinker and Abdel-Rahman, 2005 and Pintos et al., 2008). The germination of artificial seeds directly on substrates under non-sterile conditions requires sufficient nutrients to be supplied within the bead as an artificial endosperm (Pinker and AbdelRahman, 2005 and Benelli et al., 2017). Taha et al. (2013) compared synthetic seeds of Oxalis triangularis sown directly on MS basal medium, black soil and sterile black soil. They showed that conversion frequency of synthetic seeds into complete plantlets was better under in vitro than in vivo conditions.

Recently, for encapsulation, mostly Ca-alginate is used for its gel- ling properties and the suitability for plant material (Saiprasad, 2001, Islam and Bar, 2012 and Rihan et al., 2017). The beads formed after dropping the Na-alginate in $\mathrm{CaCl}_{2}$ solution $(75$ to $100 \mathrm{mM}$ ) are wet, sticky and not protected against water loss by evaporation. Moreover, it has to be expected that also bead gel matrix compounds like nutrients and growth regulators diffuse from the bead to the substrate till the chemical equilibrium is reached. So far, there are only few data available about the extent and the time course of this nutrient leakage of the beads (Redenbaugh $e t$ al., 1987 and Timbert et al., 1997).

The current experiments aimed at optimising the conversion of encapsulated nodal segments of Rosa hybrida 'Kardinal' (a tea rose cultivar used for cut flowers) cultured on a nutrient-free medium and prepared for ex vitro conversion into whole plantlets.

\section{Material and Methods}

The present experiments were conducted at Humboldt University of Berlin, Horticultural Plant Systems, Berlin, Germany during 2012 and 2013 seasons, aiming at getting more information about the nutrient requirements for growing and proliferation of encapsulated nodal segments of Rosa hybrida 'Kardinal', as well as the nutrient losses from the beads during incubation on nutrient-free media. Shoot cultures of Rosa hybrida 'Kardinal' were cultured on modified MS basal salt medium (Murashige and Skoog, 1962), and subcultured at 6 -week-intervals. The medium supplemented with $2.5 \mathrm{mg} \mathrm{l}^{-1}$ thiamin- $\mathrm{HCl}, 0.2 \mathrm{mg} \mathrm{l}^{-1}$ pyridoxin$\mathrm{HCl}, 0.2 \mathrm{mg} \mathrm{l}^{-1}$ biotin, $100 \mathrm{mg} \mathrm{l}^{-1}$ 
myo-inositol, $0.25 \quad \mathrm{mg} \quad \mathrm{l}^{-1} \quad 6$ benzylaminopurine (BAP) and 0.5 $\mathrm{mg}^{-1}$ gibberellic acid $\left(\mathrm{GA}_{3}\right), 8 \mathrm{~g} \mathrm{l}^{-1}$ agar (Serva Kobe I), and $30 \mathrm{~g} \mathrm{l}^{-1}$ sucrose. For a special pre-treatment of shoot cultures, the sucrose content was increased $\left(35,40,45\right.$, and $50 \mathrm{~g} \mathrm{l}^{-}$ $\left.{ }^{1}\right)$. The $\mathrm{pH}$ was adjusted at 5.8 before autoclaving at $121^{\circ} \mathrm{C}$ under 1.5 $\mathrm{Kg} / \mathrm{cm}^{2}$ for $15 \mathrm{~min}$. Cultures were maintained at $24 \pm 1^{\circ} \mathrm{C}$ and illuminated $16 \mathrm{~h}$ daily with $35 \mu \mathrm{mol} \mathrm{m} \mathrm{m}^{-2} \mathrm{~s}^{-1}$ photosynthetically active radiation (white light, Osram L58 W/30).

For encapsulation, 4 to $5 \mathrm{~mm}$ long nodal segments were isolated 3 weeks after subculturing. The nodal segments were put in 3\% Na-alginate (Fluka) diluted in the modified MS medium with various sucrose concentrations $(30,40,50,60,70,80$ and 90 $\left.\mathrm{g}^{-1}\right)$. The plant growth regulator was 3 -indolebutyric acid (IBA) at 0.5, 1 or $2 \mathrm{mg} \mathrm{l}^{-1}$. Droplet of 85, 95 and 105 $\mu l$ containing one segment each put into $75 \mathrm{mM} \mathrm{CaCl} 2$ solution dissolved in the same modified MS medium and slowly agitated for $30 \mathrm{~min}$. Thirty beads were used per treatment distributed to three replicates in $100 \mathrm{ml}$ Erlenmeyer flasks. Each flask contained $25 \mathrm{ml}$ water-agar-medium solidified with $8 \mathrm{~g} \mathrm{l}^{-1}$ agar (Serva Kobe I) at $\mathrm{pH} 5.8$ and was covered with aluminium foil. In the $1^{\text {st }}$ experiment, the volume of water-agar-medium was reduced from $25 \mathrm{ml}$ to 12 and 7 $\mathrm{ml}$ to improve the nutrient supply. The second experiment was carried out to investigate the effect of sucrose concentrations $(30,35,40,45$ and $\left.50 \mathrm{~g}^{-1}\right)$ in the pre-treatment propagation medium on shoot development and root regeneration of encapsulated nodal segments of $R$. hybrida 'Kardi- nal' on a water-agar-medium. Details for gel matrix compounds of the beads and water-agar-medium are indicated in the result section. The percentages of shoot development and root regeneration of rose encapsulated nodal segments were recorded after 7 weeks.

To investigate the nutrient losses from the beads to the growing medium, beads were used with a volume of $85 \mu 1$ without plant segments. Ten beads were incubated per Erlenmeyer flask with 7,12 and $25 \mathrm{ml}$ water-agar-medium. After 1 and 7 days on a water-agar-medium, 30 beads were incubated for $3 \mathrm{~h}$ in $100 \mathrm{ml} \mathrm{de}$ ionised water to leach all nutrients from the beads. The nitrate content of this solution was determined with a nitrate selective electrode (NO 500, Ingold) linked with the Ionometer (WTW 2000 mx).

All experiments were conducted 3 times. Data were evaluated with Chi-square-test (Pearson, $\mathrm{P} \leq 0.05$ ) for statistical significance.

\section{Result and Discussion \\ Effect of the bead gel matrix com- ponents}

The first experiment was conducted to investigate the effect of IBA concentrations in the bead gel matrix on rooting of rose encapsulated nodal segments on a water-agarmedium (Fig. 1). Results showed that both shoot and root formation were significantly affected by IBA concentrations. At lower IBA concentrations $\left(0.5\right.$ and $\left.1 \mathrm{mg} \mathrm{l}^{-1}\right)$, ca. 50 to $53.9 \%$ of the encapsulated nodal segments developed shoots but only 8 to $18 \%$ regenerated roots. Increasing IBA concentration from 1 to $2 \mathrm{mg} \mathrm{l}^{-1}$ significantly increased root regeneration 
from 18.0 to $48.0 \%$, but inhibited shoot development from 53.9 to $23.0 \%$ (Fig. 1). These results are quite different from that of Dendranthema $\times$ grandiflora with up to $100 \%$ conversion reported earlier in similar culture conditions (Pinker and AbdelRahman, 2005), which indicates difficulties in stimulating the conversion of rose encapsulated nodal segments. However, similar results were reported in other rose species. The shoot development was quicker and easier than root regeneration in encapsulated axillary buds of Chamaecyparis obtusa (Okamura et al., 1994) and mulberries (Pattniak and Chand, 2000). Standardi and Piccioni (1997) pointed out that rooting was always the limiting factor for conversion of encapsulated buds of apple rootstock. Piccioni (1997) suggested an auxin pulse treatment for $24 \mathrm{~h}$ and preculturing the treated nodal segments of apple rootstock for 3 to 9 days before encapsulation. Conversion of encapsulated shoot tips and nodal segments of eucalypt, Corymbia torelliana x $C$. citriodora into plantlets was achieved on half-strength MS medium by treating shoot tips or nodes with 4.9-78.4 $\mu \mathrm{M}$ IBA prior to encapsulation. Pretreatment with $19.6 \mu \mathrm{M}$ IBA provided $62-100 \%$ conversion, and 95$100 \%$ of plantlets survived after acclimatization under nursery conditions (Hung and Trueman, 2012).

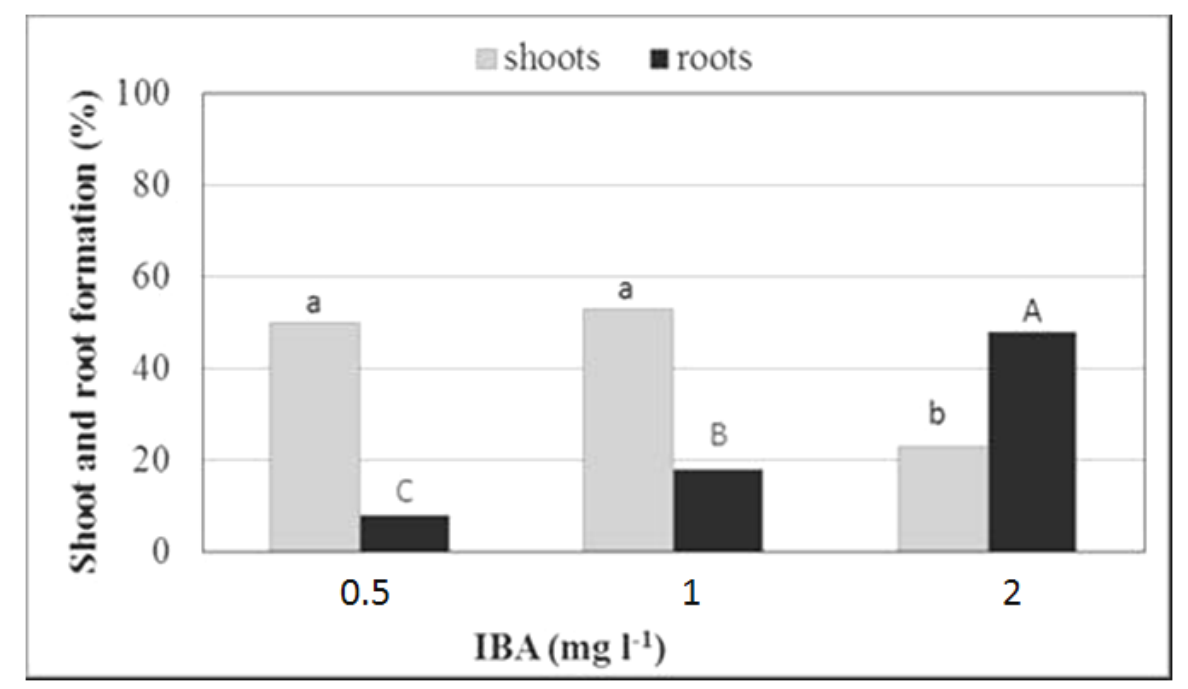

Fig. 1. Effect of IBA concentration in the bead gel matrix (MS $+30 \mathrm{~g} \mathrm{l}^{-1}$ sucrose) on shoot and root development of encapsulated nodal segments of $R$. hybrida 'Kardinal' on a water-agar-medium after 7 weeks. Different letters indicate significant differences (Chi square test, Pearson, $\mathrm{P}<0.05$ ).

However, the next experiment showed that the stimulation of shoot and root development in $R$. hybrida 'Kardinal' was also significantly dependent on the sucrose content of the beads (Fig. 2). The sucrose concentration in the bead gel matrix $(\mathrm{MS}+1$ $\mathrm{mg}^{-1}$ IBA) had to be increased even to $80 \mathrm{~g} \mathrm{l}^{-1}$ to get ca. $80 \%$ shoot development and more than 50\% root regeneration on a water-agar-medium. Redenbaugh et al. (1987) reported that sucrose represents a source of energy during the shoot proliferation 
and can speed up the regrowth of encapsulated propagules. The addition of sucrose into the artificial endosperm enhanced the germination rate of encapsulated somatic embryos in Camellia japonica (Janeiro et al., 1997) and Solanum melongena (Huda et al., 2007). Sucrose was also the principal determinant for the shoot development of encapsulated buds in Betula platyphylla (Kinoshita and Saito, 1990). In addition, Pierik (1997) investigated the effect of macronutrient and sucrose concentration on root formation on stem explants of Rosa hybrida 'Montrea'. He reported that macronutrient concentration of full strength MS was optimal for rooting response and the su- crose concentration should be 45 to $85 \mathrm{~g} \mathrm{l}^{-1}$. Rahman et al. (2002) recorded better rooting in rose with 40 $\mathrm{g}^{-1}$ sucrose than with 20 or $60 \mathrm{~g} \mathrm{l}^{-1}$. These results agree with our findings (Fig. 2) that sprouting and rooting of rose encapsulated nodal segments requires higher sugar concentrations. Calamar and De Klerk (2002) found that sucrose was essential for apple rooting especially during the first hours on rooting medium. They assumed that in microcuttings, sucrose had a direct effect on rooting by influencing the competence of cells responses to auxin as an energy source during the initial phase of regeneration.

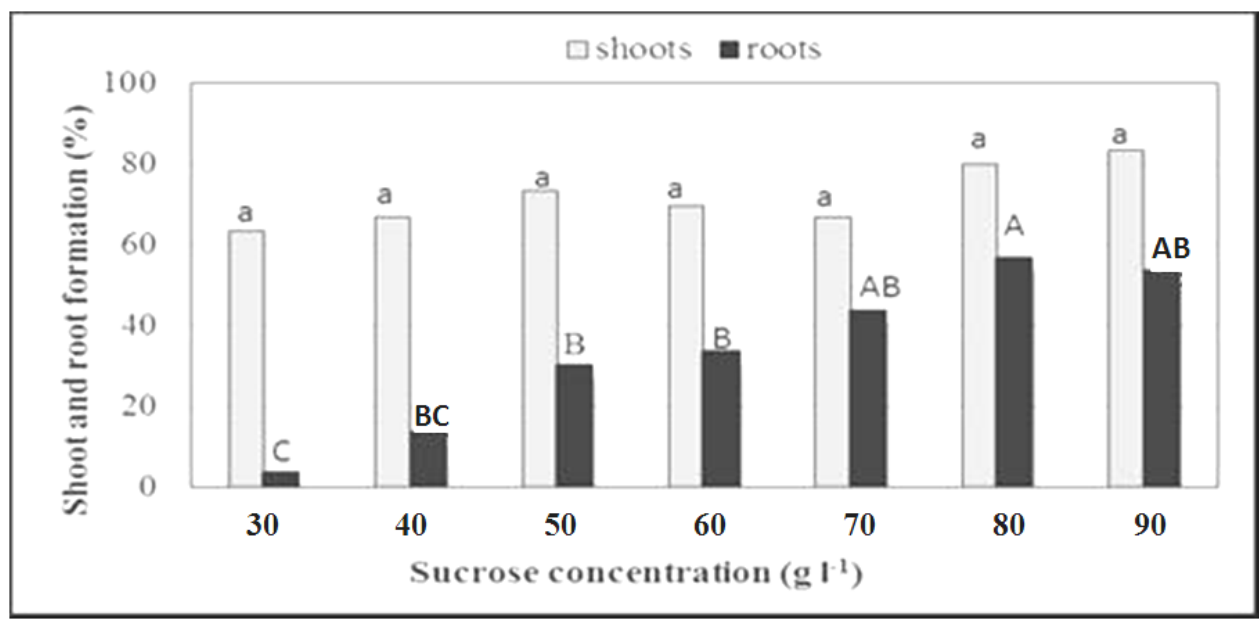

Fig. 2. Effect of sucrose concentration in the bead gel matrix (MS $\left.+1 \mathrm{mg} \mathrm{l}^{-1} \mathrm{IBA}\right)$ on development of encapsulated nodal segments of $R$. hybrida 'Kardinal' on a wateragar-medium after 7 weeks. Different letters indicate significant differences (Chi square test, Pearson, $\mathrm{P}<0.05$ ).

On the other hand, the present study showed that in beads supplied with $2 \mathrm{mg}^{-1}$ IBA, roots were regenerated before shoot development (Fig. 3 ), while in beads supplied with $1 \mathrm{mg}$ $1^{-1}$ IBA, the shoots and roots were formed at the same time (Fig. 4). However, the root formation is con- sidered to be a limiting step for conversion of artificial seeds into plantlets (Standardi and Piccioni, 1997). Therefore, $2 \mathrm{mg} \mathrm{l}^{-1}$ IBA was applied to the beads with $R$. hybrida 'Kardinal' nodal segments in the following experiments. 


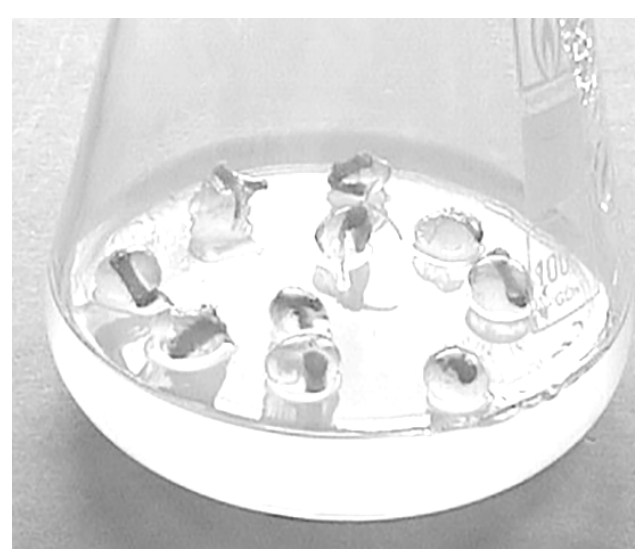

Fig. 3. Root formation of encapsulated nodal segments of $R$. hybrida 'Kardinal' after 2 weeks on a water-agar-medium and MS with 30 $\mathrm{g}^{-1}$ sucrose and $2 \mathrm{mg} \mathrm{l}^{-1}$ IBA in the bead gel matrix.

\section{Factors affecting the nutrient con- tent within the beads}

Following the time course of nitrate leakage (Table 1), it is obvious that already after $24 \mathrm{~h}$ incubation on the water-agar-medium more than $90 \%$ of nitrate was diffused out of the beads by using the standard volume of the water-agar-medium $(25 \mathrm{ml})$. That means after one day, the concentration of nutrients (based on measurement of nitrate content) in the beads is not more than a tenth of the initially added ones. Presumably, this concentration was enough to start growth and regeneration processes in Dendranthema $x$ grandiflora encapsulated nodal segments (Pinker and Abdel-Rahman, 2005). However, in $R$. hybrida 'Kardinal' encapsulated nodal segments with low levels of inorganic and organic compounds resulted in very low root regeneration (Fig. 2) as reported earlier by Pierik (1997).

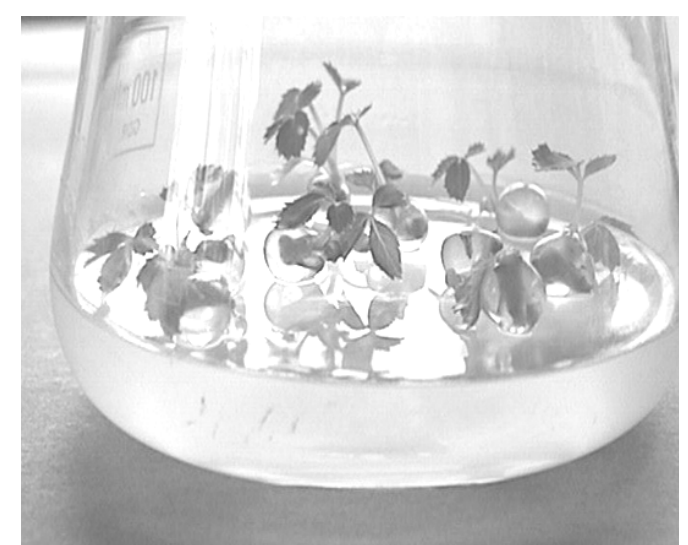

Fig. 4. Development of encapsulated nodal segments of $R$. hybrida 'Kardinal' after 7 weeks on a water-agarmedium and MS with $90 \mathrm{~g} \mathrm{l}^{-1}$ sucrose and $1 \mathrm{mg} \mathrm{l}^{-1}$ IBA in the bead gel matrix.

Some increments in the nutrient supply could be gained by reducing the volume of water-agar-medium from 25 to 12 or $7 \mathrm{ml}$ (Table 1). This little change resulted in the best shoot development achieving an increase from 40 to $90 \%$ and little improvement of root regeneration recorded an increase from 9 to $25 \%$ of encapsulated nodal segments of $R$. hybrida 'Kardinal' (Fig. 5). Timbert et al. (1997) determined diffusion of sucrose from the growing medium into the bead and vice versa, and found in alginate beads similar coefficients for both processes. Therefore, we can expect that if the nutrient concentration in the gel matrix is reduced due to the nutrient uptake by nodal segments, nutrients from the growing medium might diffuse back into the bead. 
Table 1. Nitrate leakage of beads after incubation on a water-agar-medium with different volumes for up to one week.

\begin{tabular}{|c|c|c|c|c|}
\hline \multirow{2}{*}{$\begin{array}{c}\text { Incubation period } \\
\text { (Day) }\end{array}$} & \multicolumn{4}{|c|}{ Nitrate loss (\%) } \\
\cline { 2 - 5 } & 7 & 12 & 25 & Medium volume (mI) \\
\cline { 2 - 5 } & $73.4 \mathrm{e}$ & $92.6 \mathrm{c}$ & $93.9 \mathrm{bc}$ & $86.6 \mathrm{~b}$ \\
7 & $84.5 \mathrm{~d}$ & $95.1 \mathrm{~b}$ & $97.3 \mathrm{a}$ & $92.3 \mathrm{a}$ \\
\hline Mean & $79.0 \mathrm{c}$ & $93.9 \mathrm{~b}$ & $95.6 \mathrm{a}$ & 89.5 \\
\hline LSD at $0.05 \quad$ Day $=0.02$ & Medium volume $=1.33$ & \multicolumn{4}{|c|}{ Day*Medium volume $=1.88$} \\
\hline
\end{tabular}

Different letters indicate significant differences $(\mathrm{P} \leq 0.05)$ based on LSD test.

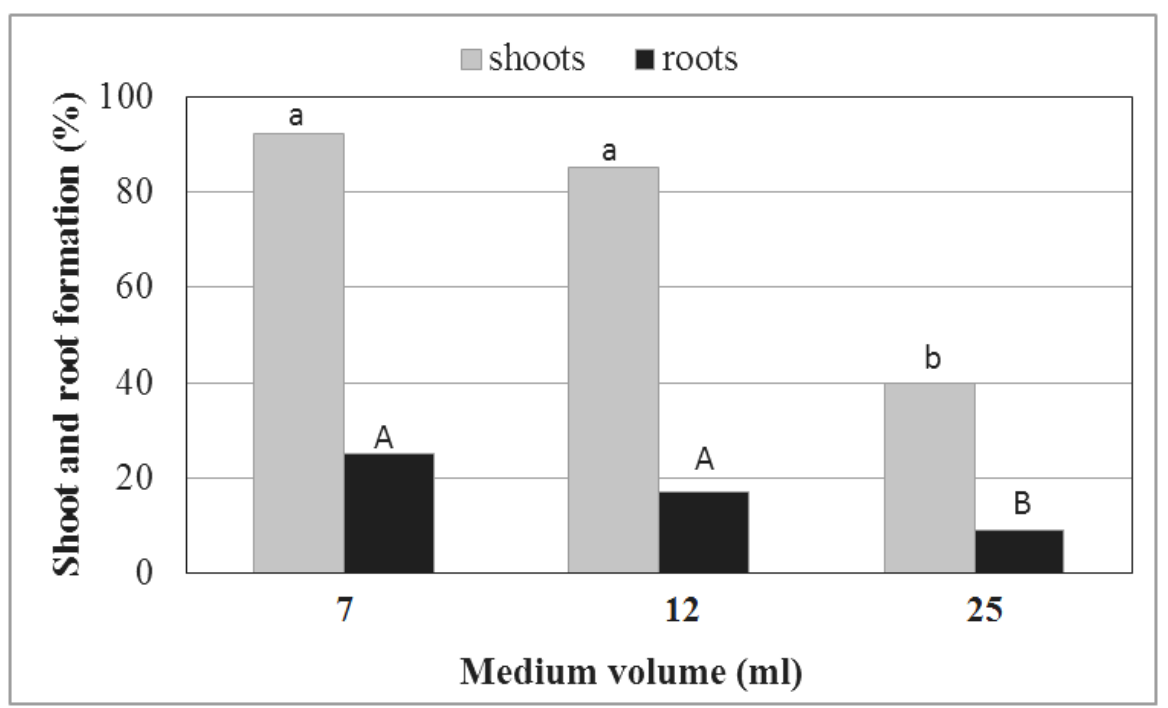

Fig. 5. Effect of volume of water-agar-medium on development of encapsulated nodal segments (MS, $90 \mathrm{~g} \mathrm{l}^{-1}$ sucrose, $2 \mathrm{mg}^{-1}$ IBA in bead gel matrix) of $R$. hybrida 'Kardinal' after 7 weeks. Different letters indicate significant differences (Chi square test, Pearson, $\mathrm{P}<0.05)$.

In another experiment, the bead volume was increased from 85 to 105 $\mu 1$ to improve the nutrient supply (Fig. 6). Indeed, the increase in root regeneration was improved from 40 to $70 \%$ whereas shoot development was not significantly affected and ranged between 30 and $40 \%$. The observed inhibition of shoot develop- ment could be due to the higher IBA concentration used in this experiment. Therefore, using MS with $1 \mathrm{mg}^{-1}$ IBA and $90 \mathrm{~g} \mathrm{l}^{-1}$ sucrose as an artificial endosperm resulted in the highest conversion $(50 \%)$ of encapsulated nodal segments of $R$. hybrida 'Kardinal' on a water-agar-medium. 


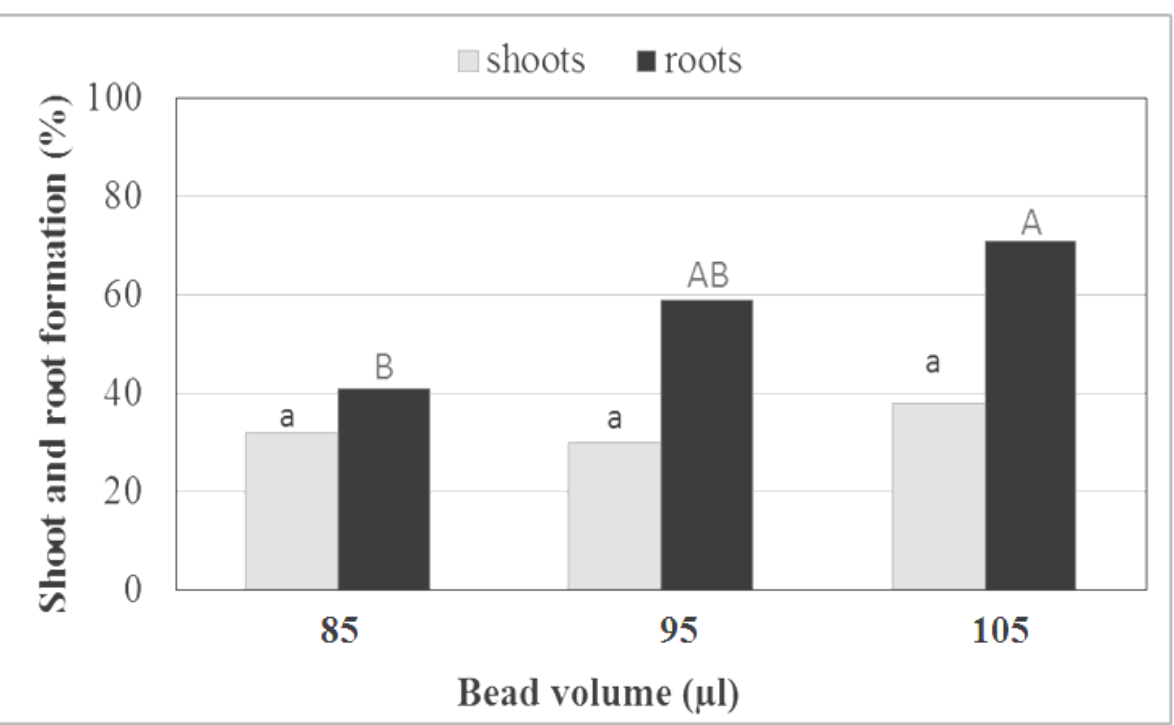

Fig. 6. Effect of bead volume on development of encapsulated nodal segments (MS, 90 $\mathrm{g} \mathrm{l}^{-1}$ sucrose, $2 \mathrm{mg} \mathrm{l}^{-1}$ IBA in bead gel matrix) of $R$. hybrida 'Kardinal' after 7 weeks. Different letters indicate significant differences (Chi square test, Pearson, $\mathrm{P}<0.05)$.

\section{Effect of sucrose enrichment of the propagation medium}

Because in $R$. hybrida 'Kardinal' it was not possible to supply enough nutrients within the beads, the effect of pre-treatment of the shoot cultures by cultivation on media with enhanced sucrose concentration (up to $50 \mathrm{~g} \mathrm{l}^{-1}$ ) has been investigated. Data showed that increasing sucrose concentration in the propagation medium improved root regeneration of rose encapsulated nodal segments with up to $80 \%$ whereas the shoot development was reduced from 60 to $10 \%$ at the same time (Fig. 7). Tawfik et al. (2018) reported that medium with $\mathrm{pH}$ at 5.5 supplemented with 50 $\mathrm{g}^{-1}$ sucrose produced the highest significant value of rooting (85\%) and enhanced root formation in 7.5 days. Similar observations were obtained by Mamiya and Sakamoto (2000), who found that sugar concentration in the post-culture medium affected the growth of shoots and roots in the conversion process. Lower concentrations of sugar promoted the growth of shoots, but higher concentrations of sugar promoted the growth of roots and inhibited the growth of shoots of somatic embryos in Asparagus officinalis. 


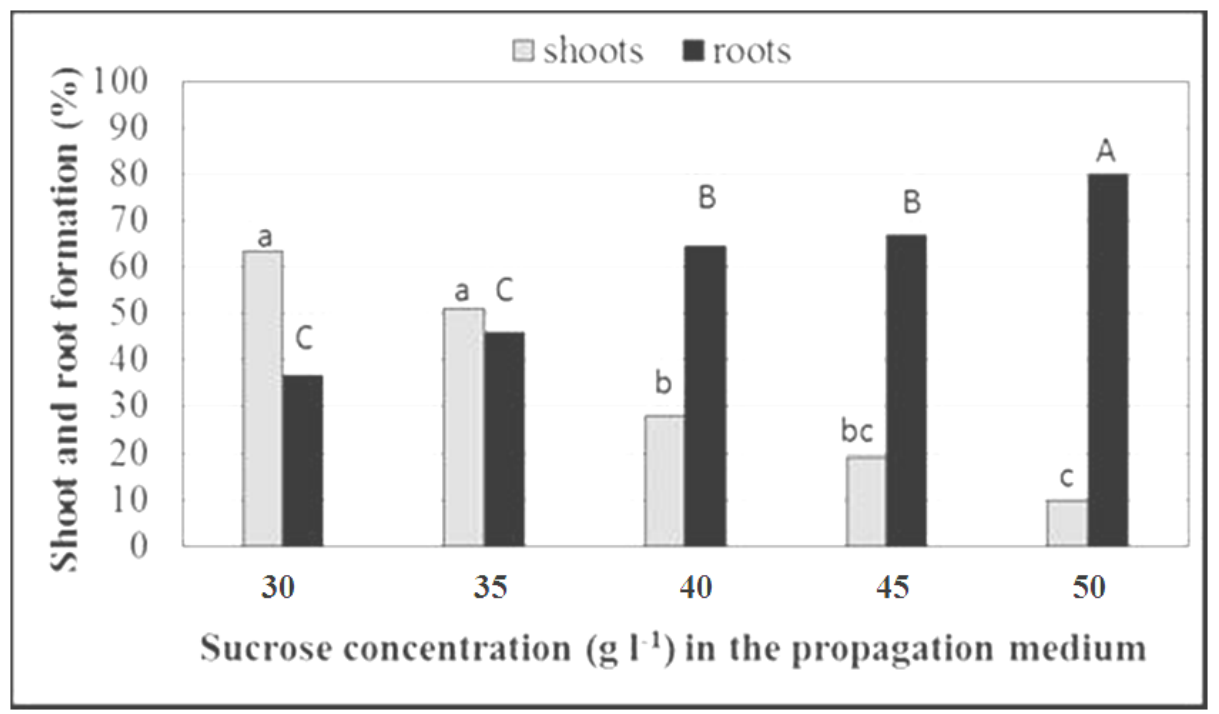

Fig. 7. Effect of sucrose concentration in the pre-treatment propagation medium on shoot and root formation of encapsulated nodal segments (MS, $90 \mathrm{~g} \mathrm{l}^{-1}$ sucrose, 2 $\mathrm{mg} \mathrm{l}^{-1}$ IBA in bead gel matrix) of $R$. hybrida 'Kardinal' on a water-agar-medium after 7 weeks. Different letters indicate significant differences (Chi square test, Pearson, $\mathrm{P}<0.05)$.

\section{Conclusions}

The present results clearly indicated that the conversion rate of rose encapsulated nodal segments into plantlets was low on a nutrient-free medium. Maximum conversion rate (ca. $53 \%$ ) was obtained by use of MS with $1 \mathrm{mg} \mathrm{l}^{-1}$ IBA and $90 \mathrm{~g} \mathrm{l}^{-1}$ sucrose as an artificial endosperm on a wateragar medium. The nutrients included in the gel matrix of the calcium alginate bead diffuse rapidly into the nutrient-free substrate (ca. 90\% nutrients loss after $24 \mathrm{~h}$ incubation). The remaining nutrients were not sufficient to stimulate shoot development and root regeneration of cultures with high nutrient demands like rose. In this study, the nutritional status of the beads could be slightly manipulated by reducing the volume of growing media or increasing the bead volume. Therefore, it is suggested that further investigations should be carry out to improve conversion rate of rose en- capsulated nodal segments into plantlets on a nutrient-free medium.

\section{References}

Benelli, C.; M. Micheli and A. De Carlo (2017). An improved encapsulation protocol for regrowth and conservation of four ornamental species. Acta Societatis Botanicorum Poloniae, 86(3): pp. 3559. https://doi. org/10.5586/asbp.3559

Calamar, A. and G.J. De Klerk (2002). Effect of sucrose on adventitious root regeneration in apple. Plant Cell, Tissue and Organ Culture, 70: 207-212.

Carlson, C.H. and T.P. West (2016). Nodal encapsulation of Cercidiphyllum japonicum Sieb \& Zucc. and Cercidiphyllum magnificum Nakai. Propagation of Ornamental Plants, 16: 84-89.

Chand, S. and A.K. Singh (2004). Plant regeneration from encapsulated nodal segments of Dalbergia sissoo Roxb., a timber-yielding leguminous tree species. Journal of Plant Physiology, 161: 237-243. 
Elangomathavan, R.; N.S. Beaulah; S. Hariharan and P. Kalaivanan (2017). Encapsulation of shoot tips and nodal segments of Cleistanthus collinus for short term storage and germplasm exchange. International Journal of Current Research in Biology and Medicine, 2(1): 2132.

Gantait, S.; J. Vijayan and A. Majee (2017). Artificial Seed Production of Tylophora indica for Interim Storing and Swapping of Germplasm. Journal of Horticultural Plant, 3(1): 41-46.

Gholami, A.A. and B. Kaviani (2018). Somatic embryogenesis, encapsulation, cold storage and growth of hybrid Citrus ( $C$. paradise Macf. "Duncan" x C. reticulata Blanco. "Dancy" shoot tip segments. Indian Jpurnal of Biotechnology, 17: 134-144.

Huda, A.K.M.N.; M. Rahrnau and M.A. Bari (2007). Effect of carbon source in alginate bead on synthetic seed germination in eggplant (Solanum melongena L.). Journal of Plant Science, 2: 538-544.

Hung, C.D. and S.J. Trueman (2012). Alginate encapsulation of shoot tips and nodal segments for shortterm storage and distribution of the eucalypt Corymbia torelliana x C. citriodora. Acta Physiological Plant, 34: 117-128.

Islam, M.S and M.A. Bar (2012). In vitro regeneration protocol for artificial seed production in an important medicinal plant Mentha arvensis L. Journal of Biomedical Science, 20: 99-108.

Janeiro, L.V.; A. Ballester and A.M. Vieitez (1997). In vitro response of encapsulated somatic embryos of camellia. Plant Cell Tissue Organ Culture, 51: 119-125.
https://doi.org/10.1023/A:1005958 827202

Kinoshita, I. and A. Saito (1990). Propagation of Japanese white birch by encapsulated axillary buds. 1. Regeneration of plantlets under aseptic conditions. Journal of the Japanese Forest Society, 72(2): 166170.

Lata, H.; S. Chandra; T. Natascha; I.A. Khan and M.A. El Sohly (2011). Molecular analysis of genetic fidelity in Cannabis sativa L. plants grown from synthetic (encapsulated) seeds following in vitro storage. Biotechnology Letters, 33: 2503-2508.

Mamiya, K. and Y. Sakamoto (2000). Effects of sugar concentration and strength of basal medium on conversion of somatic embryos in $A s$ paragus officinalis L. Scientia Horticulturae, 84: 15-26.

Maruyama. E.; I. Kinoshita; K. Ishii; K. Ohba and A. Saito (1997). Germplasm conservation of the tropical forest trees, Cedrela odorata L., Guazuma crinita Mart. and Jacaranda mimosaefolia D. Don. by shoot tip encapsulation in calcium alginate and storage at $12-25{ }^{\circ} \mathrm{C}$. Plant Cell Rpt., 16: 393-396.

Murashige, T. (1977). Plant cell and organ culture as horticultural practices. Acta Horticulturae, 78: 1730.

Murashige, T. and F. Skoog (1962). A revised medium for rapid growth and bioassay with tobacco cultures. Physiologia Plantarum, 15: 473-479.

Okamura, M.; M. Seneda and T. Kondo (1994). Rooting from encapsulated adventitious buds of Hinoki (Chamaecyparis obtusa). Journal Japanese Forest Society, 76(6) 601-603. 
Pattniak, S.K. and P.K. Chand (2000). Morphogenetic response of the alginate-encapsulated axillary buds from in vitro shoot cultures of six mulberries. Plant Cell, Tissue and Organ Culture, 60: 177-185.

Piccioni, E. (1997). Plantlets from encapsulated micropropagated buds of M.26 apple rootstock. Plant Cell, Tissue and Organ Culture, 47: 255-260.

Pierik, R.L.M. (1997). Factors controlling adventitious root formation on stem explants of rose (Rosa hybrida "Montrea") in vitro, in: Altman, A., Waisel, Y. (Eds.). Biology of Root Formation and development. Plenum Press, New York, pp. 297-307.

Pinker, I. and S.S.A. Abdel-Rahman (2005). Artificial seeds for propagation of Dendranthema x grandiflora. Propagation of Ornamental Plants, 5: 186-191.

Pintos, B.; M.A. Bueno; B. Cuenca and J.A. Manzanera (2008). Synthetic seed production from encapsulated somatic embryos of cork oak (Quercus suber L.) and automated growth monitoring. Plant Cell Tissue and Organ Culture, 95(2): 217225.

Rahman, S.M.; M. Hossain; A.K.M.I. Rafiul and O.I. Joarder (2002). Effects of media composition and culture conditions on in vitro rooting of rose. Scientia Horticulturae, 52: 163-169.

Rai, M.K.; V.S. Jaiswal and U. Jaiswal (2008). Encapsulation of shoot tips of guava (Psidium guajava L.) for short-term storage and germplasm exchange. Scientia Horticulturae, 118: 33-38.

Redenbaugh, K.; D. Slade; P. Viss and J.A. Fujii (1987). Encapsulation of somatic embryos in synthetic seed coats. HortScience, 22(5): 803809.
Rihan, H.Z.; F. Kareem; M.E. ElMahrouk and M.P. Fuller (2017). Artificial Seeds (Principle, Aspects and Applications). Agronomy, 7(4): 1-15.

https://doi.org/10.3390/agronomy7 040071

Rout, G.R.; S. Samantaray; J. Mottley and P. Das (1999). Biotechnology of the rose: a review of recent progress. Scientia Horticulturae, 81: 201-228.

Saiprasad, G.V.S. (2001). Artificial seeds and their applications. Resonance 5, 39-47.

Sakamoto, Y.; S. Umeda and H. Ogishima (1991). Artificial seed comprising a sustained-release sugar granule. United States Patent, 5: 010-865.

Sharma, S.; A. Shahzad and J.A. Teixeira da Silva (2013). Synseed technology - A complete synthesis. Biotechnology Advanced, 31: 186-207.

Sharma, V. and A. Sharma (2018). Synthesis of Indigenous callus culture and artificial seeds from Celastrus paniculatus Willd.via nodal segments. International Journal of Advanced Scientific Research and Management, Special Issue I, 105109.

Singh, S.K.; M.K. Rai; P. Asthana and L. Sahoo (2010). Alginateencapsulation of nodal segments for propagation, short-term conservation and germplasm exchange and distribution of Eclipta alba L. Acta Physiological Plant, 32: 60710.

Standardi, A. and E. Piccioni (1997). Rooting induction in encapsulated buds of M.26 apple rootstock for synthetic seed, in: Altman, A., Waisel, Y. (Eds.), Biology of Root Formation and Development. Ple- 
num Press, New York, pp. 309314.

Standardi, A. and M. Micheli (2012). Encapsulation of in-vitro-derived explants: An innovative tool for nurseries, in: Lambardi, M., Ozudogru, E.A., Jain, S.M. (Eds.), Protocols for Micropropagation of Selected Economically Important Horticultural Plants, Methods in Molecular Biology. Springer Science, New York, pp. 397-418.

Taha, R.M.; N. Mahmad; J.S. Yaacob; N. Abdullah and S. Mohaje (2013). Synthetic seeds production and regeneration of Oxalis triangularis for mass propagation and conservation. International Journal of Environmental Science and Development, 4(5): 461-464.

Tawfik, A.A.; O.H.M. Ibrahim; E.Y. Abdul-Hafeez and S.A.I. Ibrahim
(2018). Optimizing micropropagation protocol for Rosa hybrida cv. Eiffel Tower with improved in vitro rooting ability. Egypt. J. Hort., 45(2): $323-335 . \quad$ DOI: 10.21608/ejoh.2018.4906.1075

Teixeira da Silva, J.A. (2004). Ornamental chrysanthemums: improvement by biotechnology. Plant Cell, Tissue and Organ Culture, 79: 1-18.

Timbert, R.; J.N. Barbotin and D. Thomas (1997). Choice of the matrix for encapsulating and dehydrating carrot somatic embryos: Importance of the rheology, the desorption and the diffusion parameters. In: Ellis R. H., Black M., Hong T. D. (Eds.). Basic and applied aspects of seed biology. Kluwer Academic Publishers, Dortrecht, 63-73. 
تحول العقد الساقية المكبسلة فى نبات الورد صنف كاردينال إلى نباتات كاملة معمليا

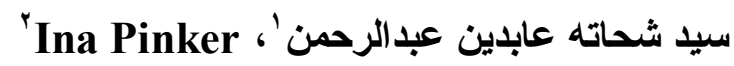

$$
\begin{aligned}
& \text { ' قسم نباتات الزينة وتتسيق الحدائق ـ كلية الزر اعة - جامعة أسيوط - مصر } \\
& \text { r جامعة همبولدت ببرلين - نظم نباتات البساتين - برلين - ألمانيا }
\end{aligned}
$$

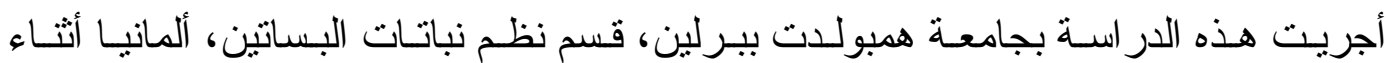

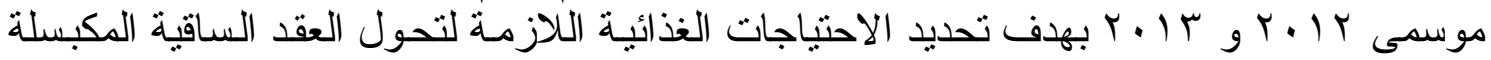

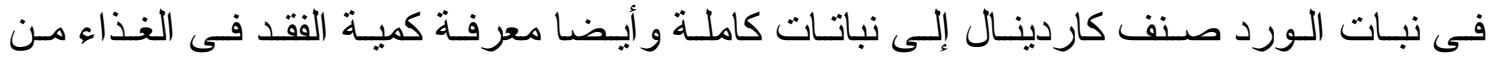

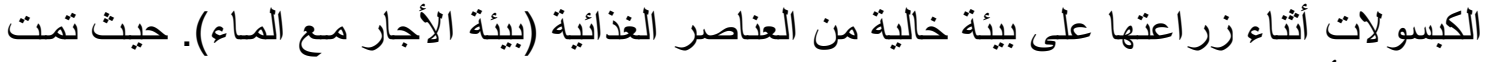

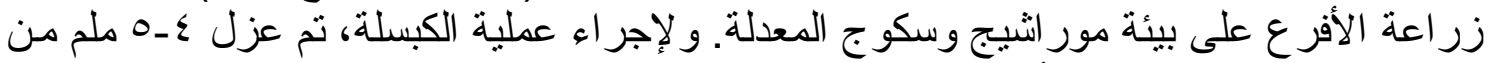

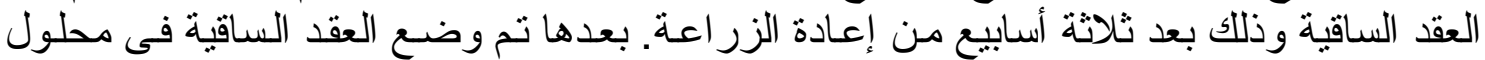

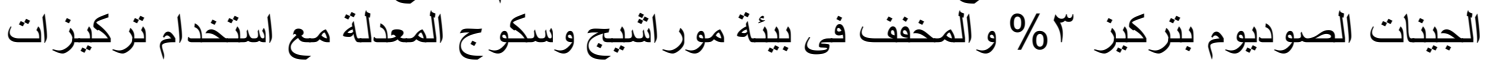

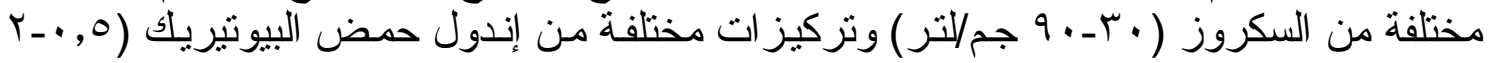

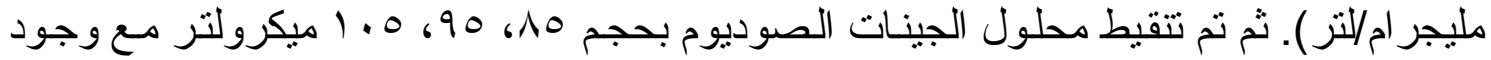

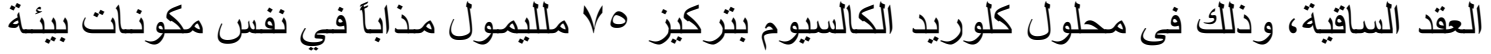

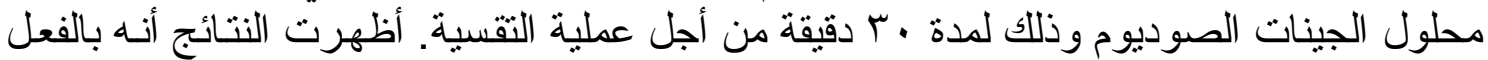

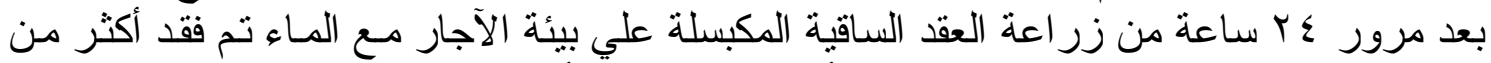

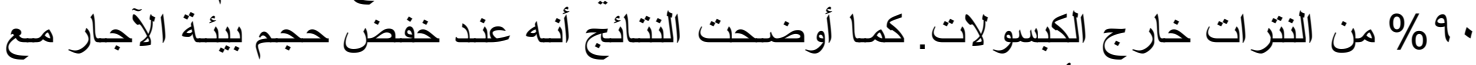

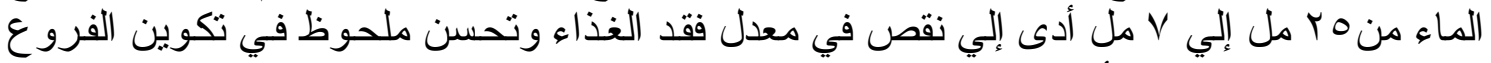

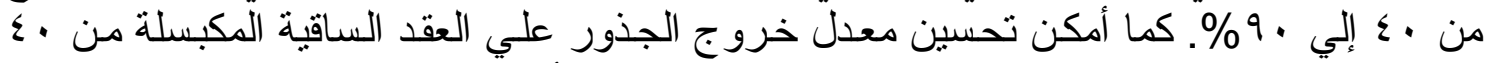

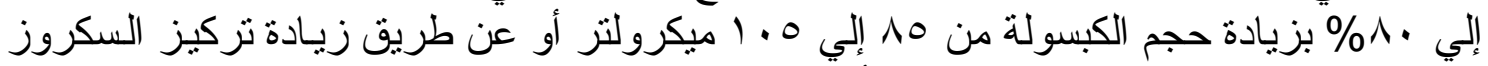

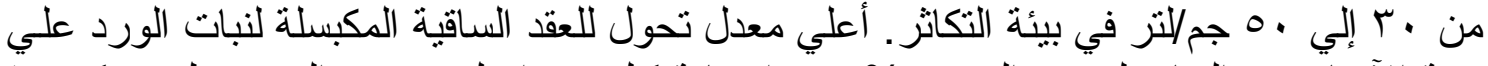

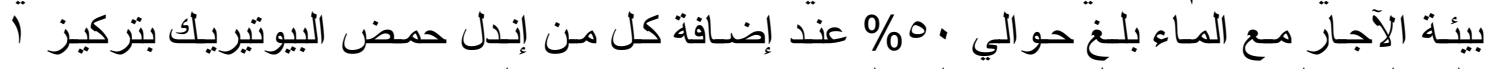
ملجم/لتز و السكروز بمعدل • 9 جم/لتز إلي مكونات الإندوسبرم الصناعي. 